理で除去されたため結晶化度が高くなり鮮明度が増したすのと考 えられる。しかし窒亲学囲気での加熱処理る，高温であれば結晶 化度は向上するにすかかからず鮮明さが酸素察聿気よりいくら゙ん
贫る傾向がある。この点は結晶表面および内部の微細構造炕す原 因があると考えられるので，今後の検討祼題としたい。

\title{
Effects of Atmospheric Gases on the Change of Crystal Structure or Colour of Cadmium Pigments during Heat Treatments ${ }^{\dagger}$ \\ Makoto Tsunashima* and Hiroshi Taxahashi** \\ * Mitsubishi Metal Corporation; Kitabukuro-machi, Omiya-shi, Saitama, Japan \\ ** The Institute of Industrial Science, University of Tokyo; Roppongi, Minato-ku, Tokyo, Japan
}

Effects of atmospheric gases on the change of the crystal structure or colour of various cadmium pigments in the course of heat treatment were studied. The samples used in this experiments were precipitates having the compositions of the following four kinds, that is, CdS, $\beta-\mathrm{CdS}, 2 \mathrm{CdS} \cdot \mathrm{ZnS}$ and $1.5 \mathrm{CdS} \cdot\left(\mathrm{CdCO}_{3} \cdot \mathrm{Se}\right)$. As atmospheric gases, dried oxygen of high purity, nitrogen and helium were used.

The precipitates of the various samples, after outgassing for $1 \mathrm{hr}$. under the conditions of $200^{\circ} \mathrm{C}$ and $10^{-s} \mathrm{mmHg}$, were heat-treated at $400,500,600$ or $700^{\circ} \mathrm{C}$ in atmospheric gases. The changes in the physico-chemical properties due to heat treatment, despite the difference in the compositions of the various samples, showed a similar tendency. The oxygen atmosphere which was active toward the pigments improved the crystallinity and increased the brightness of colour, while nitrogen and helium, inert atmosphere, had little effects.

Crystallization and $\beta \rightarrow \alpha$ phase transition took place preferentially on the crystal surface and in fine particles.

$\uparrow$ Studies of Cadmium series pigments. IV.

\section{カドミウム系顔料の加熱処理による粒子特性と色調の変化 ${ }^{122)}$}

\author{
(1972 年 5 月 9 月受理) \\ 綱 島 真*. 高 橋 浩**
}

前報2) K引きつつきカドミウム系顔料の加熱処理過程における諸物性の变化を検討した。武料は表 1 と示した 4 種

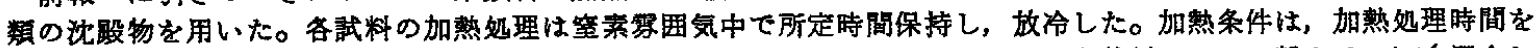
1,5 および 25 時間とし, 温度を $400,500,600$ および $700^{\circ} \mathrm{C}$ としたさららに各試料にイオウ粉を 1 wt\%混合し て加熱処理を行ない，このイオウと雾囲気の窒素および酸素との相関関係を険討した。

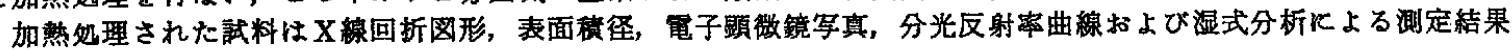
から解析を行なった。

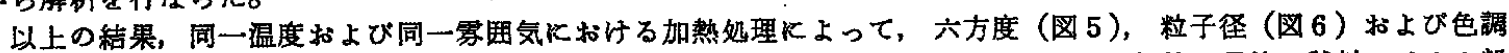
（因 14）の変化が 5 時間を越えると急激に小さくなり䬲和することが認められた。すた加熱処理前の試料にイオウ粉 を 1 wt \% 混合すると加熱処理の効果法抑制される。前報2) 飞示された需囲気酸素による加熱处理の促進効果を合わ せると，イオウと酸素がたがいに逆の协果をるつことが確かめられた。

\section{1. 粕曹}

カドミウム系顔料の湿式製法においては溶液反应工程と狫成工 程の二つが重要な工程である。まず溶液反応工程では CdS, CdS$\mathrm{CdCO}_{3}-\mathrm{Se}$ 系, $\mathrm{CdS}-\mathrm{ZnS}$ 系なる組成の沈䛯を作成する。これを

1）この報文を“カドミウム系顔料の研究(第５報）”とする.

2）前報(第 4 報)，綱島 真，高橋 浩，日化，1972，1788.

* 三蕧金属鉱業株式会社大宫工場，大宮市北袋町

** 東京大学生産技術研究所, 東京都港区六本木
乾燥後 $500 \sim 700^{\circ} \mathrm{C}$ で加熱処理することによって所定組成をるっ た固溶体結晶が形成される。これを粉矺して黄色から赤色の顔料 が得られる。このうちの烍成工程に拈ける条件（時間，温度，雾 囲気）を変化させたとき，粒子の成長と結晶の多形転移なとが起 こり，色調がそれにとるなっていちじるしく変化する。

粉体の加熱処理過程においては, 成分の気化, 固相反応, 粒子 (結晶) 成長, 結晶多形転移などが起こる。これまでに加熱処理 による粒子の成長に関しては， $\mathrm{Gray}^{3)}$ の $\mathrm{ZnO}$ に関する報告や，

3) T.J.Gray, J.Amer. Ceram.Soc., 37, 534(1954). 
圾口ら゙の ZnS 飞関する報告化示されるように，一定条件のもと

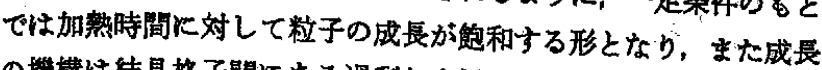
の機構は結晶格子間にある過䣋な金属 $\left(\mathrm{Z}_{\mathrm{n}}\right)$ の体積拻散であると

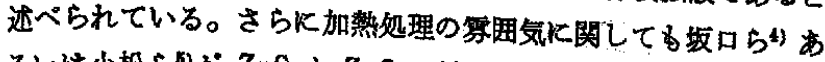

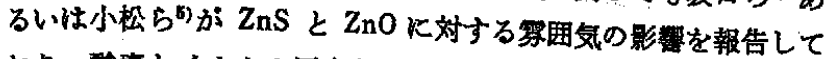
おり，酸染とイオウの反応あるいは表面㕣への吸着なとの举動も かなり論じられている。しかしカドミウム系顔料に関する加熱処 理過程の詳細な報告は少ない。

本報告ではカドミウム系顔料の粒子成長，結晶多形転移䗆よび

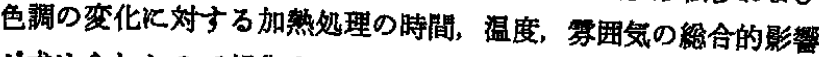
が求められたので報告する。

\section{2 実験}

カドミウム系顔料の加熱処理過程飞おいては，結晶（粒子）の 成長，低温安定形結晶（ $\beta$ 型）から高温安定形 ( $\alpha$ 型)への多形 転移，固溶体の形成などが起こる。表1に示した本実験試料の場 合，CdS 組成の試料阔しては粒子成長之多形転移か门起こり， CdS-ZnS 系の試料ではこれk加えて両成分の固溶体の形成が 起 こる。また CdS-CdSe 系㳊関しては加熱処理の初期飞 $\mathrm{CdCO}_{3}-$ Se-CdS の反応によって CdS-CdSe の形成と，とれらの固溶体が 形成される過程があり，䊉子成長がこれに加わる。さらに $\mathrm{B}-\mathrm{CdS}^{6}$ は粒子が表 1 K示したように大きく、結晶形は 加熱処理によって主として多形転移が起こる。このように 4 種の 試料は，加熱処理によってそれぞれ異なった变化を含せのでこの 点を考慮する必要がある。

また，前報2)の結果化よって加熱姏理の雾囲気のうち，酸素が 窒素に比較して加熱処理の効果を促進することが認められてお ク,この酸素が加熱処理時汇試料中の成分元素と反応することる 考えられる。したがってここではくくイイオウを取り上げ，加熱 処理前の試料にイオウ粉を混合して加熱処理を行ない，イオウ添 加による加熱处理試料の諸物性の变化を険討した。イオウは bp $444.6^{\circ} \mathrm{C}$ であるので $500^{\circ} \mathrm{C}$ 以上の加熱処理温度では気体となって おり，雾囲気ガスの一種ともいえる。イオウを混合した場合の加 熱処理においては，雾围気酸素との反応による二酸化イオウの生 成あるいは $\mathrm{CdS}-\mathrm{CdCO}_{\mathrm{g}}-\mathrm{Se}$ の反応時にイオウが 加わることによ って CdS と CdSe の固溶比の変化などが起こると考光られる。

これまでの報告2)で結晶転移に関してはカドミウム乘顔料の加 熱処理温度が $600^{\circ} \mathrm{C}$ 以になるとほとんど

Table 1 Original samples

\begin{tabular}{lccc} 
Sample & $\begin{array}{c}\text { Surface } \\
\text { area } \\
\left(\mathrm{m}^{2} / \mathrm{g}\right)\end{array}$ & $\begin{array}{c}\text { Particle }^{a)} \\
\text { size } \\
(\mu)\end{array}$ & $\begin{array}{c}\text { Content of } \\
\text { hexagonal- } \\
\text { form }^{b)}\end{array}$ \\
\hline $\mathrm{CdS}$ & 97.4 & 0.013 & $<60$ \\
$2 \mathrm{CdS} \cdot \mathrm{ZnS}$ & 117.6 & 0.011 & $<60$ \\
$2 \mathrm{CdS} \cdot \mathrm{CdSe} \mathrm{C}^{()}$ & 43.9 & 0.027 & $<60$ \\
$\beta-\mathrm{CdS}$ & 7.6 & 0.168 & 18
\end{tabular}

a) By BET method.

b) By X-ray diffractometry.

c) Mixed $\mathrm{CdS}-\mathrm{CdCO}_{3}-\mathrm{Se}$ precipitate.

4）坂口雅一，平林孝圆，日化，89，253，258(1968).

5）小松和藏, 守吉佑介, 寧協, 80, 37(1972).

6） 2 種の CdS 組成の試料を区别するため, 表 1 K示したよ 3 に今後 $\mathrm{CdS}$ と $\beta$-CdS そkわけて表示する.
示した。

カドミウム系顔料の一般的製法では，カドミウム塩水溶液，重 鉊塩水溶液飞対して硫化ナトリウム水溶液（セレンを加える昜合 は所要量をこの溶液中に溶解する) を加えることによって，CdS， $\mathrm{CdS}-\mathrm{ZnS}$ あるいは $\mathrm{CdS}-\mathrm{CdCO}_{\mathrm{g}}-\mathrm{Se}$ の非晶筫に近い微結晶粒子を 沈殿させる。この方法飞よって，本実験の試料 CdS, $2 \mathrm{CdS} \cdot \mathrm{ZnS}$, $\mathrm{CdS}-\mathrm{CdCO}_{3}-\mathrm{Se}$ を作成した。また，前報点と同じ $\beta$-CdS を加え て 4 種類を本実験の加熱処理陚料として用いた。

以上の 4 試料の物性は表 1 に示した。

試料の加熱処理の条件は，温度を $400 ， 500 ， 600$ および $700^{\circ} \mathrm{C}$ とし，また処理時間は 1，5，25 時間とした。陚料は石英ポート 飞充满し，石英板のカバーをして所定温度の横型管状炉内装入 した。そのときの温度が所定の温度にるどるまでに要した時間は

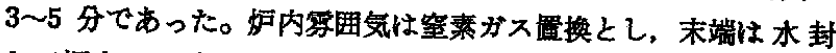
して妒内をはぼ大気任にたもつよらにした。また，イオウ粉を渥 合した試料を加熱処理する場合は前報》で述へた妒を用い，娍压 脱ガスを $200^{\circ} \mathrm{C} ， 10^{-3} \mathrm{mmHg} ， 60$ 分間行ない，その後雾因気ガ スを導入して所定温度で 1 時間加熱処理した。

各加熱观理試料柱 X線回折図形，表面積，電子影徽鏡写真以よ る粒子径和よび分光反射率曲線を測定したが，湘定条件は前報》 に述べた条件と同じである。X線回折図形は $\mathrm{Cu} K_{\alpha}$ 線を用いた。 表面積は液体窒素温度に枋ける窒素吸着法から BET 法により求

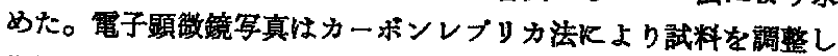
撮影した。

\section{3 結果およひ考察}

\section{1 加熱処理時間の効果}

3.1.1 結晶多形転移: 加熱処理過程に 枋ける 各試料の X線回 折図形を図 1, 図 2 に示す。CdS-CdSe 系および CdS-ZnS 禾に ついては CdS 試料の場合とはとんど同じX線回折図形であるの で省略する。

これら試料の結晶多形は常温では低温安定形の $\beta$ 型 (Zincblende 型) 々高温安定形の $\alpha$ 型 (Wurtzite 型) があるが, 通常 $600^{\circ} \mathrm{C}$ 以上の加热処理で $\alpha$ 型に転移する。Short らはこの $\alpha$ 型結 晶が試料中に占める割合を求めるための実験式を提出した7)。結 晶中に $\alpha$ 型占占める割合を便宜上六方度 (Content of hexagonalform) としてHで表わし，図 $1 \sim 2$ にみられるょらに $2 \theta=20$ 人

\section{CdS}

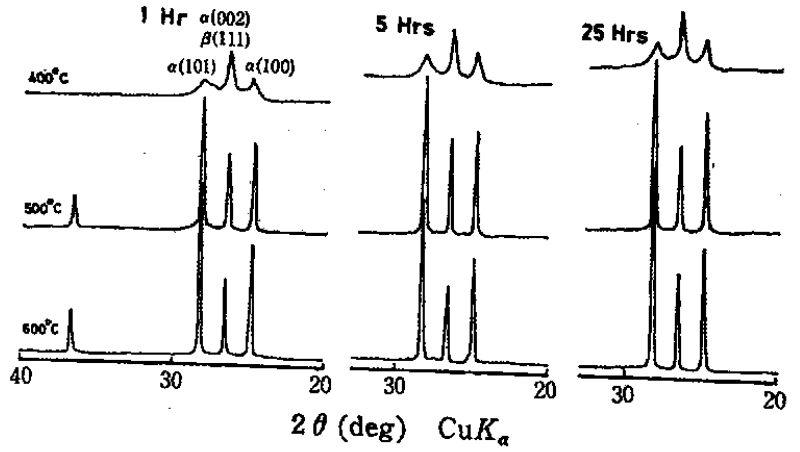

Fig. $1 X$-ray diffractometry traces of CdS

7) M. A. Short, E. G. Steward, Amer. Mineral, 44, 189 


\section{$D-\cos$}

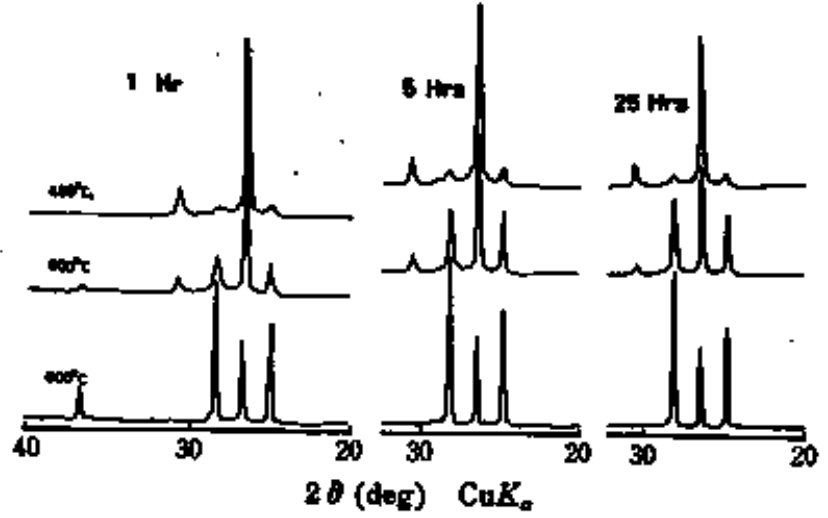

Fig. 2 X-ray diffractometry traces of $\beta$-CdS

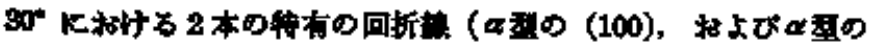

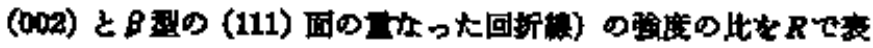
わすと.これらの网雨は式のよるになる。

$$
\begin{aligned}
& H=4 R /(3 R+I .93) \times 100(\%) \\
& R=I(100) /[I(002)+I(111)\}
\end{aligned}
$$

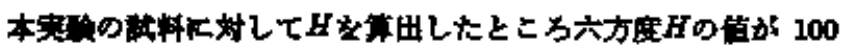

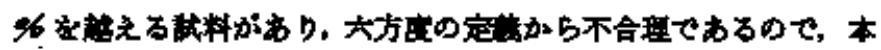

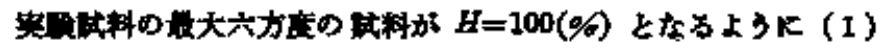

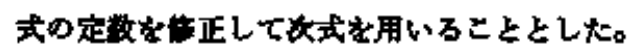

$$
H=4 R /(3 R+1.70) \times 100
$$

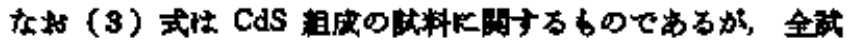
料飞年用して相奶的六力在を比謨した。

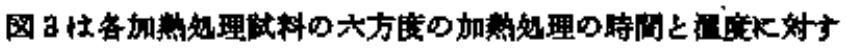

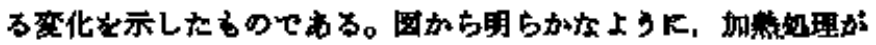

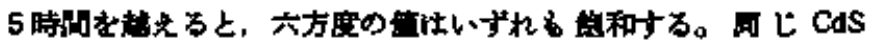

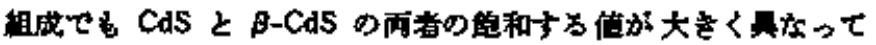

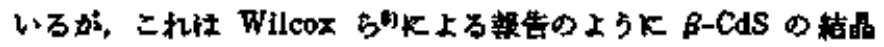

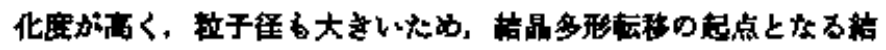

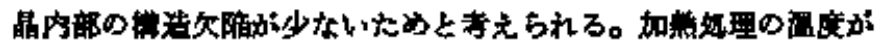

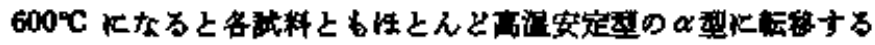

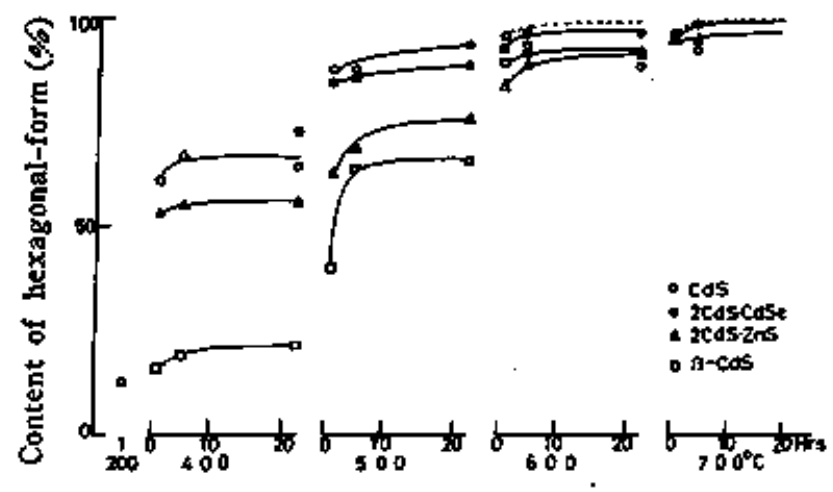

Heat treatment (time and temperature)

Fig. 3 Changes in content of hexagonal-form of heat-treated samples

B) D. B. HoIt D. M. Wilcox, J. Crystal Growth, 9, 193 (1971).

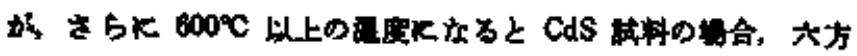

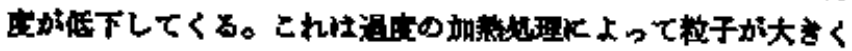

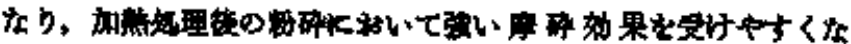

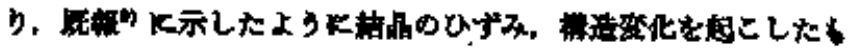
のと考えられ。

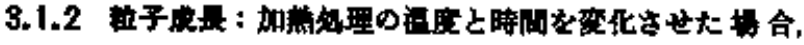

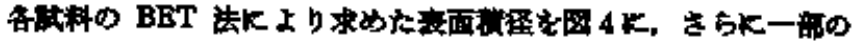

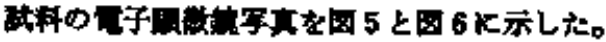

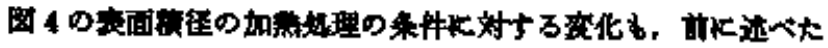

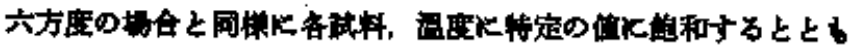

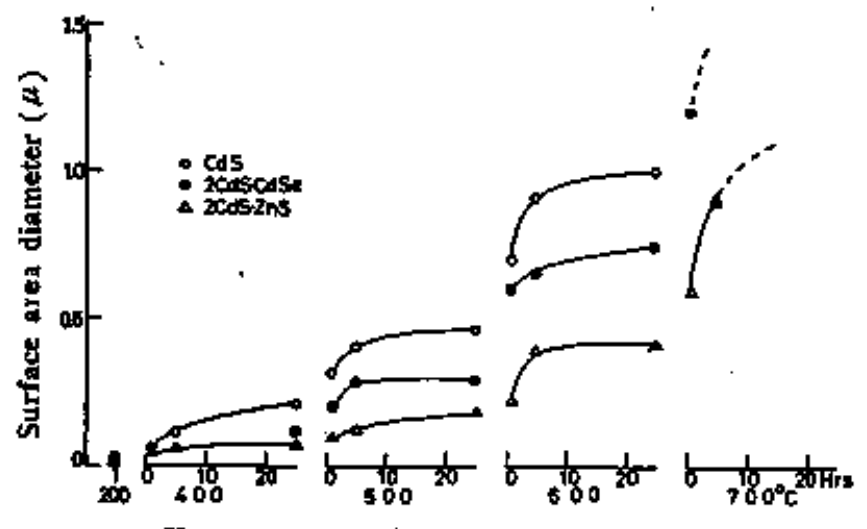

Heat treatment (time and temperature)

Fig. 4 Changes in particle size of heat-treated samples

\section{Cds (6000)}

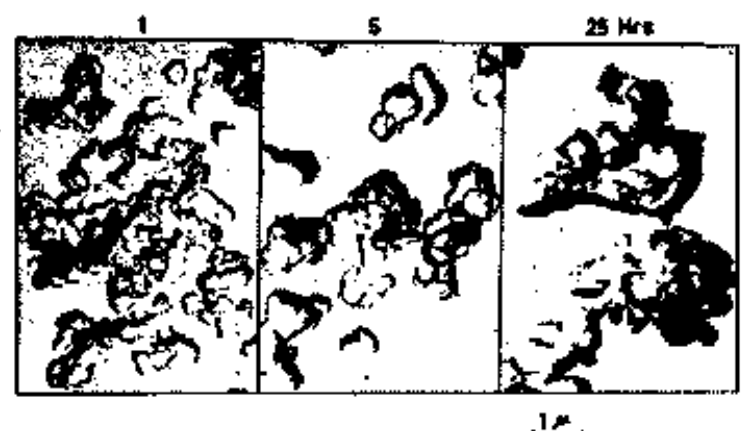

Fig. 5 Electron micrographs of heat-treated specimens of CdS

B-CdS ( s00t)

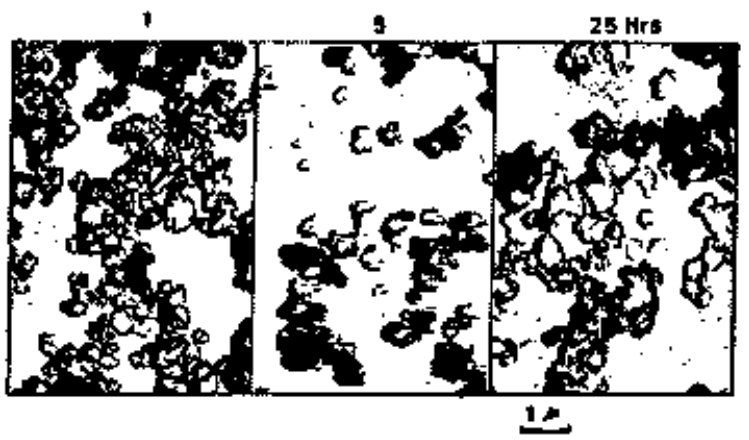

Fig. 6 Electron micrographs of heat-treated specimens of $\beta-C d S$

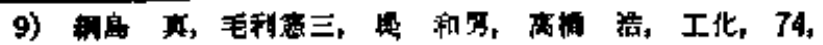
$1733(1971)$. 
に，その粒子径は図 5 の電子暴改鏡写真から得られる粒子径と上 く一致している10)。また図6にみられるよらK，もとる粒子径 の大艺い $\beta$-CdS 試料は加熱処理によって他の試料のようないち しるしい粒子成長はしなかった。

3.1.3 色調の変化 : 色調の表示法は前報》飞詳細仁記したよ5 飞分光反射率曲線を用いる。たとえば各曲線飞和ける $50 \%$ 反射 率を示す一点を考党れば，その点の波長が色相を表わし，また立 ち上がり勾配が鮮明さを表わしている。

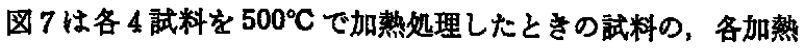
处理時間飞战ける分光反射率曲線の变化を示したるのである。加 熱処理の時間が長くなるにしたがって，各試料とも分光反射率曲 線の立ち上がり勾配恃大きくなり，色調は鮮明となる。図8，9 は加熱処理の時間が 5 時間の場合の各加熱処理温度飞培ける各試 料の分光反射率曲線を示す。各試料によって差はあるが，加熱処 理の温度が高くなり，試料の結晶（粒子）が大きくなると澌定に

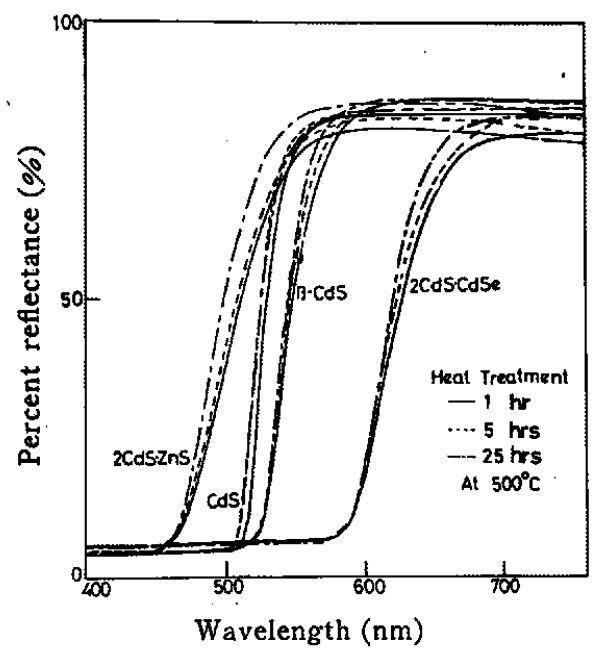

Fig. 7 Spectral reflectance curves of $500^{\circ} \mathrm{C}$ heat-treated specimens

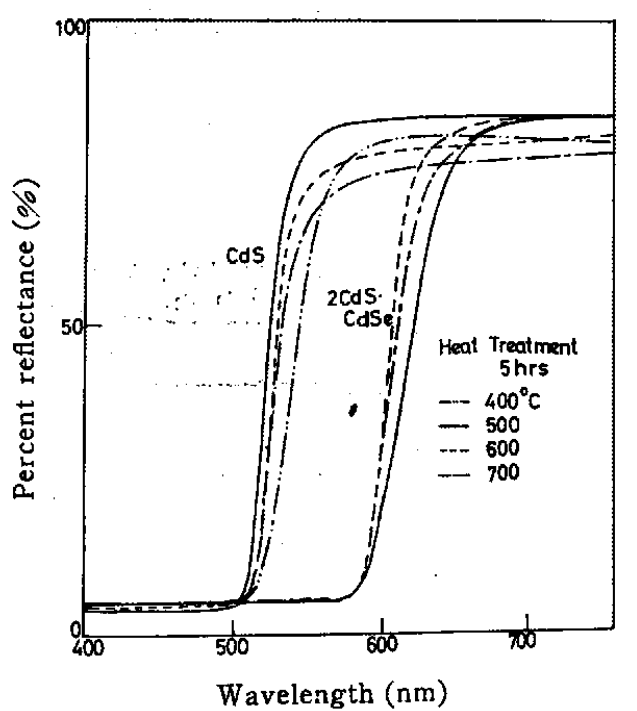

Fig. 8 Spectral reflectance curves of $\mathrm{CdS}$ and $2 \mathrm{CdS}$. CdSe in the process of heat treatment

10) CdS-CdSe 系坊よび CdS-ZnS 系試料の電子顕微鏡写真す CdS 試料の場合と同㥞, BET 法表面樌径とよい一致を示 したので省略した.

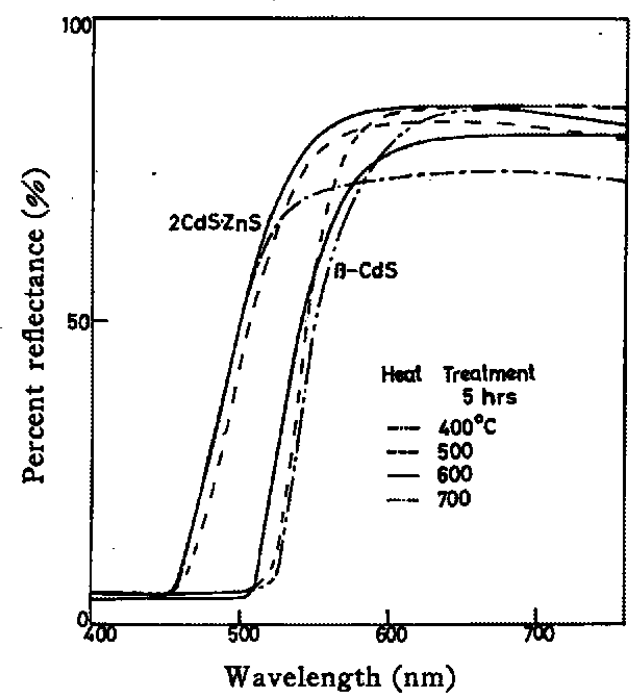

Fig. 9 Spectral reflectance curves of $\beta$-CdS and $2 \mathrm{CdS}$. $\mathrm{ZnS}$ in the process of heat treatment

供する場合の粉碎、混練に执いて摩碎効果9をを受けやすくなり。 結晶の鹤造変化やひずみを生して分光反射率曲線の立ち上がり勾 配も小さくなってくる。本実験の試料の場合る, 試料の組成，履 歴によって限界温度は異なるが，約 $600^{\circ} \mathrm{C}$ まで加熱処理で恃温 度の上年とともに分光反射率曲線の立ち上がり勾配が大きくな り，色相は黄味でかつ解明になっていく。しかし，この限界温度を 越えると图 8，9 KみられるようK，加熱処理試料の粉碎，混練 時にいちしるいい暗赤色化が起こる。 $\beta$-CdS 試料に関しては 500 ${ }^{\circ} \mathrm{C}$ 以上で $\beta \rightarrow \alpha$ 結晶転移が起こるため， $\alpha$ 型への転移とともに 色相は黄味となっていく変化がさらに加わるため, 色調は袮雅な 变化をする。

3.1.4 総合 : 以上の六方度，粒子径および色調の玟化を総合 的化比較すると，加熱処理前の試料の結晶化度が高く，粒子径が 他の試料の約 10 倍である $\beta$-CdS 試料の婸合は変化が少し異な るが，その他の試料に対する加熱処理の効果はすべて同じ挙動を 示した。本実験の結果と前報》の加熱処理の雾囲気による影響も 含めて考えると，加熱处理条件（雾囲気, 温度, 時間) の美異に よる試料の粒子 (結晶) 成長，多形転移战よび色調の变化が CdS, $\mathrm{CdSe}, \mathrm{ZnS}$ (その他，㕲そらく $\mathrm{HgS} ＼textrm{Z n S e}$ なとの周期率表の

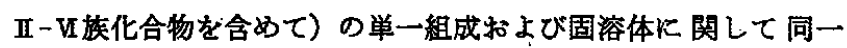
傾向をるつことが推察される。

加熱処理の温度を一定にして，時間を变えた場合，六方度およ び粒子径が特定の值に飽和する傾向がみられ，各試料とる約 5 時 間で飽和值炕達した。また加熱処理が 5 時間を越えたのちすわず かではあるが色調の鮮明度が増加（分光反射率曲線の立ち上がり 勾配が大となる）している点を考光ると，この段階では顔料粉体 の全体的な結晶化度の向上が主として起こっているとみられる。 加熱処理の初期飞括ける粒子成長に関しては Kuczynski ${ }^{11)}$

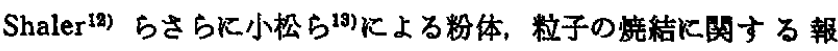
告があり，これらの中に述べられているように格子間にある金属 （本実験では（Cd, $\mathrm{Zn})$ が粒子間の接触部作体皘（結晶内）拻散

11) G. C. Kuczynski, J. Appl. Phys., 20, 1160(1949).

12) A. T. Shaler, J. Wulff, Ind. Eng. Chem., 40, 838(1948).

13）小松和藏, 守吉佑介, 䇥協, 80, 37(1972). 
Table 2 Physical properties of heat-treated samples

\begin{tabular}{|c|c|c|c|c|c|c|c|c|c|c|}
\hline \multirow{3}{*}{ Sample } & \multirow{2}{*}{\multicolumn{2}{|c|}{ Atmosphere }} & \multicolumn{8}{|c|}{ Temperature $\left({ }^{\circ} \mathrm{C}\right)$} \\
\hline & & & \multicolumn{2}{|c|}{400} & \multicolumn{2}{|c|}{500} & \multicolumn{2}{|c|}{600} & \multicolumn{2}{|c|}{700} \\
\hline & Sulfuras & Gas & $H(\%)^{b)}$ & $d(\mu)^{c)}$ & $H$ & $d$ & $H$ & $d$ & $H$ & $d$ \\
\hline \multirow{4}{*}{ CdS } & & $\mathbf{N}_{2}$ & - & 0.06 & 70 & 0.11 & 92 & 0.28 & 95 & - \\
\hline & & $\mathrm{O}_{2}$ & - & 0.07 & 78 & 0.14 & 93 & 0.42 & 95 & - \\
\hline & \multirow[b]{2}{*}{1} & $\mathrm{~N}_{2}$ & - & -0.05 & 65 & 0.09 & 86 & 0.18 & 93 & - \\
\hline & & $\mathrm{O}_{2}$ & - & 0.06 & 70 & 0.12 & 91 & 0.31 & 94 & - \\
\hline \multirow{4}{*}{$2 \mathrm{CdS} \cdot \mathrm{CdSe}$} & \multirow{2}{*}{0} & $\mathrm{~N}_{2}$ & $\longrightarrow$ & - & 65 & 0.07 & 85 & 0.21 & 97 & 0.60 \\
\hline & & $\mathrm{O}_{2}$ & 一 & - & 69 & 0.07 & 90 & 0.20 & 98 & 0.61 \\
\hline & \multirow{2}{*}{1} & $\mathrm{~N}_{2}$ & - & - & 68 & 0.08 & 86 & 0.35 & 97 & 0.78 \\
\hline & & $\mathrm{O}_{2}$ & - & - & 71 & 0.06 & 92 & 0.19 & 98 & 0.60 \\
\hline \multirow{4}{*}{$2 \mathrm{CdS} \cdot \mathrm{ZnS}$} & \multirow{2}{*}{0} & $\mathrm{~N}_{2}$ & - & 一 & 61 & 0.07 & 78 & 0.15 & 90 & 0.22 \\
\hline & & $\mathrm{O}_{2}$ & - & - & 66 & 0.08 & 85 & 0.17 & 92 & 0.27 \\
\hline & \multirow{2}{*}{1} & $\mathrm{~N}_{2}$ & - & - & 60 & 0.06 & 70 & 0.14 & 85 & 0.21 \\
\hline & & $\mathrm{O}_{2}$ & - & - & 61 & 0.07 & 77 & 0.15 & 90 & 0.23 \\
\hline \multirow{2}{*}{\multicolumn{11}{|c|}{$\begin{array}{l}\text { a) Sulfur wt } \% \text { admixed to original samples before heat treatment. } \\
\text { b) Content of hexagonal form (wurtzite). }\end{array}$}} \\
\hline $\begin{array}{l}\text { b) Con } \\
\text { c) Sur }\end{array}$ & & & & & & & & & & \\
\hline
\end{tabular}

していきそこでイオウまたはセレンと結晶を形成して成長して いくと考えられる。この結晶格子の形成の段階では結晶多形転移 る同時に起こり，そのときの六方度は温度に依存する。通常 500 ${ }^{\circ} \mathrm{C}$ 以上の加熱処理を行なう場合は高温安定形の $\alpha$ 型が形成され. 粒子成長のいちじるしい場合忹ど六方度が大きくなると考えられ る。

\section{2 加热処理贯围気の効果}

前報2)では加熱処理の雾囲気，また前項では温度と時間を変化 させた場合の各試料の結晶多形転移と粒子径の変化を求め,さら 飞各特性と色調との相関が得られた。その結果，とくに酸素の存 在が熱処理において大きな効果をすつことがわかったので，もし 試料中のカルコゲン (S, Se) に対する金属 $(\mathrm{Cd}, \mathrm{Zn})$ の比が化学 量論的当量からずれている場合は雾囲気酸素との相互作用が考え られる。したがってここでは粉末イオウを各試料に 混合したの ら，窒素および酸素察囲気中で加熱処理を行ない，イオウおよび 酸素の効果を検討した。イオウは $\mathrm{mp} 119^{\circ} \mathrm{C}$, bp $444.6^{\circ} \mathrm{C}$ である ので本実験の加熱処理温度では気体として存在し, 雾囲気気体と

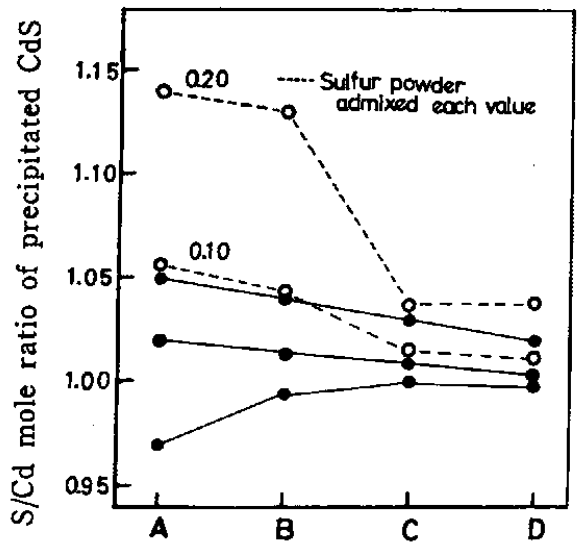

Fig. 10 Changes in $S / C d$ mole ratio of heat-treated specimens of $\mathrm{CdS}$

A Precipitate heat-treated $60 \mathrm{~min}$, at $100^{\circ} \mathrm{C}$

B " " " at $200^{\circ} \mathrm{C}, 10^{-3} \mathrm{mmHg}$

C Sample B " " $"$ at $400^{\circ} \mathrm{C}$, in $\mathrm{N}_{2}$

$\mathrm{D} " \| \quad " \quad "$, in $\mathrm{O}_{2}$
しての効果をあつと考えられる。

まず CdS 組成の沈殿物に対して予備加熱观理を行ない，それ

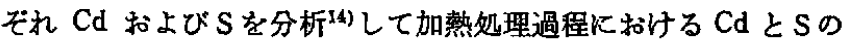
挙動を S/Cd モル比の形で求めて図 10 に示した。図 10 からCd が化学量論的にSより過剩な場合, 加熱温度 $200^{\circ} \mathrm{C}$ 以上で Cd が より多く離脱して Cd と Sの化学量諭的当墨比近つく。逆にSが $\mathrm{Cd}$ より過剩な試料では加熱温度 $400^{\circ} \mathrm{C}$ になると急激に $S$ の離脱 が起こり，どちらが過剩であっても加熱処理によって最終的には 注化学量論的当量に近づくといら結果が得られた。

以上の結果，イオウを混合する場合でも原試料の組成が問題と なる。本実験では CdS, CdS-CdSe 系, CdS-ZnS 系とも(S+Se)/ $(\mathrm{Cd}+\mathrm{Z})$ モル比が約 0.97 であり，イオウ粉末を 1 wt \% 混合し たのちはしたがって 1.02 程度である。

3.2.1 六方度と粒子径：図 11 には CdS 組成の試料を窒素雾 囲眇飞括いて加熱処理した試料のX線回折図形を示す。図の左側 は原試料のまま，右側は原試料に $1 \mathrm{wt} \%$ (S/Cd モル比約 0.05 相当）のイオウ粉末を混合した試料をそれ、ぞれ絰素䨘囲気中で加 熱処理した結果である。これから試料にイオウ粉末を混合するこ

\section{$\cos$}

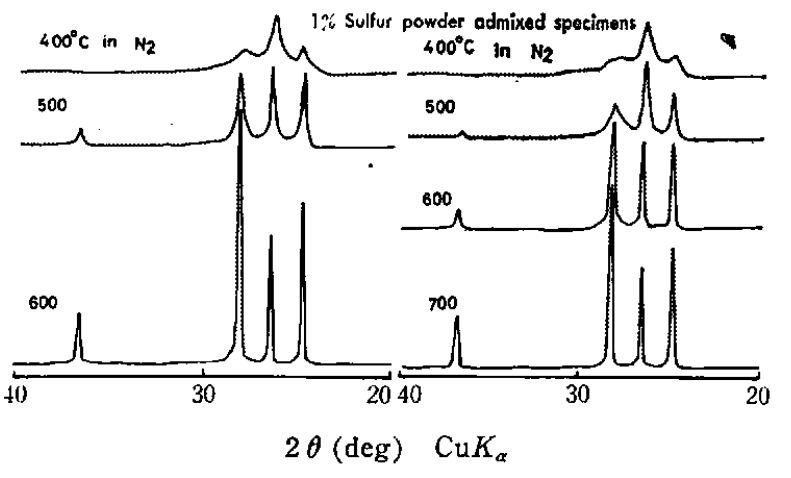

Fig. $11 X$-ray diffractometry traces of heat-treated specimens of original sample and a sample admixed with $1 \%$ sulfur before heat treatment

14）Cd に関しては EDTA 滴定法，Sに関しては重量法を用 いた. 
とによって結晶化度就よび 倾向がみられる。

つぎK加熱処理の試料として CdS, CdS-CdSe 系および CdS$\mathrm{ZnS}$ 系の 3 種類の試料扰よびそれにイオウ粉末を混合した試料を

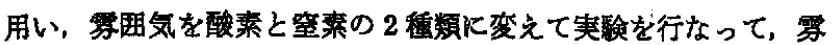
囲気酸素とイオウの相互作用を検討した。この結果を前化述べた 六方度むよび表面樌径（粒子径）の二つの特性值で裴わし表 2 K 示した。

イオウの混合効果は CdS および CdS-ZnS 系の試料に 対して は，加熱処理の效果を抑制するが CdS-CdSe 系の試料に対しては 促進效果がみられる。これは後者が加熱処理過程に执いて $\mathrm{CdCO}_{5}$ とSe, S との反応が起こるが，この過程において混合イオウが存 在すると CdSe あるいは CdS の生成に有効であるためである。 前者の 2 試料の結果からこの反応段階が含まれない場合，イオウ 混合炕よって結晶（粒子）成長と六方度の向上が抑制されるとい ら結果が得られた。したがって, CdS-CdSe 系す反応終了後は CdS および CdS-ZnS 系と同㥞にイオウ混合によって粒子成長と 多形転移が㧕制されると考えられる。

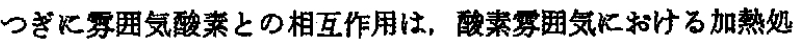
理においては，混合したイオウが酸化され(5)、イオウおよび酸素 がともに存在しない場合（原試料，窒案雾囲気）とほぼ同じ結果 となった。 3 試料とす酸素雾囲気の場合は窒素掌囲気に比較して 粒子成長と六方度は促進されるが，これが酸素自体の効果か，あ るいはイオウとの相互作用によるすのかは今後の検討課題とした W。

3.2.2 色調の变化 : 図 12,13 Kはイオウ粉の混合による CdS および CdS-CdSe 系の試料の分光反射率曲線の変化を示した。

$\mathrm{CdS}$ および $2 \mathrm{CdS} \cdot \mathrm{ZnS}{ }^{18)}$ の加熱処理雾囲気に関しては酸素の 方が空素にくらへて立ら上がり勾配が大きく鮮明な色調となって いる。またイオウ粉の混合によって各試料とも立ち上がり公配が 減少して混合前の試料より鮮明度が低下している。これらは前項 の六方度および粒子径に対する効果と強い相関がある。イオウ粉 混合の効果が酸素との相互作用によって相殺されている点る同様 である。

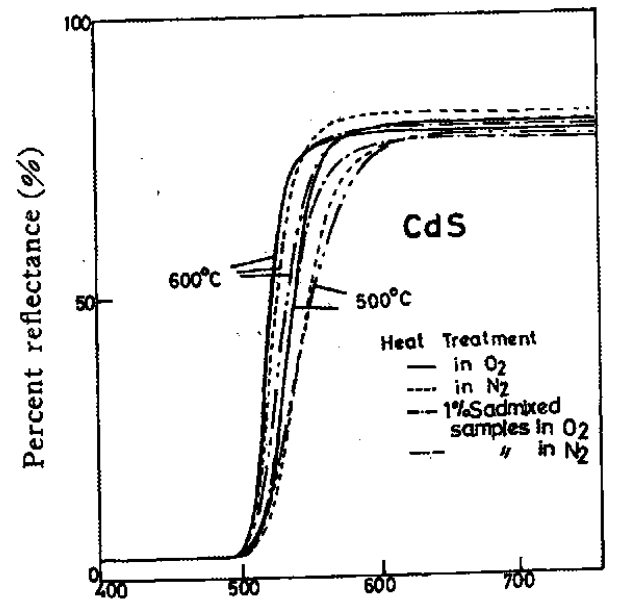

Wavelength $(\mathrm{nm})$

Fig. 12 Spectral reflectance curves of heat-treated $\mathrm{CdS}$ specimens at various conditions

15）定性的飞二酸化イオウが検出された.

16） CdS の場合と非常に類似している結果なので四は省略する.

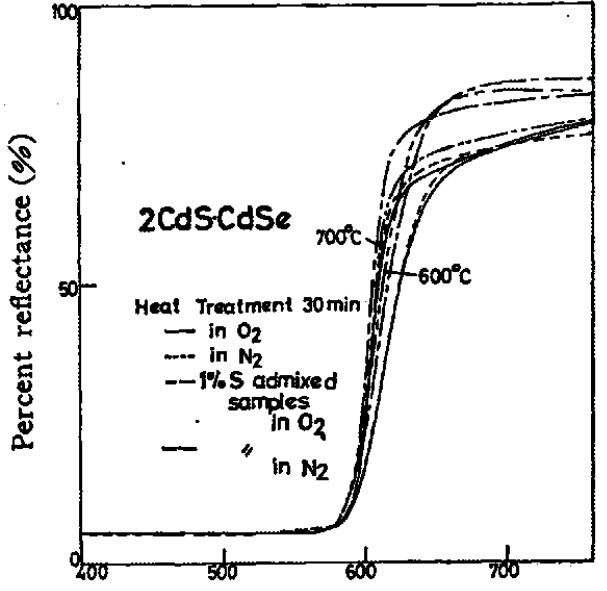

Wavelength (nm)

Fig. 13 Spectral reflectance curves of heat-treated $2 \mathrm{CdS} \cdot \mathrm{CdSe}$ specimens at various conditions

$2 \mathrm{CdS} \cdot \mathrm{CdSe}$ 組成の試料に関してす前に述べたように加熱処理 の初期飞 $\mathrm{CdCO}_{3}$ と $\mathrm{Se}(\mathrm{S})$ との反応が起こり，このとき混合した イオウ粉が反応に関与し, $2 \mathrm{CdS} \cdot \mathrm{CdSe}$ 組成より CdS 成分が少し 多い組成のものが生成することが考えられるが、ここで混合した 1 wt \% 程度のイオウ量では, 分光反射率曲線の吸収端の位㐤と $\mathrm{X}$ 線回折図形の回折線の位㯰（回折角）の変化は小さく，ほとん ど空められなかった。

\section{4 結鎬}

4.1：加熱処理化よる CdS, CdS-CdSe 系扰よび CdS-ZnS 系 の多形転移，粒子(結晶) 成長および色調の変化は，基本的に強 い相関があることが示された。

4.2 : 加整知理の時間に対する六方度（結晶中に $\alpha$ 型の含まれ る割合）と粒子径の変化は，同一温度，同一雪囲気において各試 料とす約 5 時間で洼ほ館和した形となる。しかしその後も色調は 鮮明になっていくことから，結晶化度の向上は継続して進んでい るとみられる。

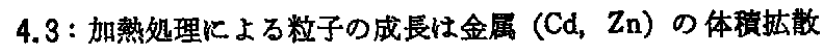
による粒子接触部の $S(\mathrm{Se})$ との再結合によって起こり，その時 期に高温安定型の $\alpha$ 型が形成されるため，粒子の成長と六方度の 相関が強いと考えられる。

4.4 : 試料の色調の解明度は結晶化度の高いるのほと大きい。

4.5: 試料中化イオウ $1 \mathrm{wt} \%$ を混合した場合, CdS-CdSe 系 の沈䟝物では $\mathrm{CdCO}_{3}$ と $\mathrm{Se}(\mathrm{S})$ の反応は完成されていないので, 加熱処理による Cd-Se の反応には有奻である。CdS, CdS-ZnS 系に関しては加熱処理による六方度，粒子径の增加に対して㧕制 效果を示した。

4.6 : 加熱処理の雾囲㐭として酸素を用いた場合は六方度の向 上と粒子の成長を促進する效果をるっているが，酸素雾囲気中で イオウ混合試料を加熱処理した場合，酸素とイオウの効果が相殺 されて，窒素等囲気中でイオウを混合しない試料の場合とほば同 じになった。

4.7: 溶液反伈に括いて非当量の S/Cd モル比をるった沈股物 を作成しこれを加熱処理および㳦压処理したのち S/Cd モル比 を分析によって求めた絬果，イオウ過 剩試料のイオウの離脱は 
$200^{\circ} \mathrm{C}, 10^{-3} \mathrm{mmHg}$ では少なく, $400^{\circ} \mathrm{C}$ では急激飞多くなる。む たイオウ粉老泥合した場合は $400^{\circ} \mathrm{C} の$ 加熱処理沉よっていちじる しいイオウの離脱を起こした。カドミウム過剩の沈殷物では Cd
の離脱があり，どちらが過剩の場合も $400^{\circ} \mathrm{C}$ 以上の加熱処理で化 学量諭的当量化近づいた。

\title{
Changes in Particle States and Color by Heat Treatment of Cadmium Series Pigments ${ }^{\dagger}$
}

\author{
Makoto Tsunashima* and Hiroshi Takahashi** \\ * Mitsubishi Metal Corporation; Kitabukuro-machi, Omiya-shi, Saitama, Japan \\ ** The Institute of Industrial Science, University of Tokyo ; Roppongi, \\ Minato-ku, Tokyo, Japan
}

In this paper, changes in some particle properties and color of cadmium pigments by heat treatment were studied. Samples used in this study were precipitates of four kinds, that is $\mathrm{CdS}, \beta-\mathrm{CdS}, 2 \mathrm{CdS} \cdot \mathrm{ZnS}$ and $2 \mathrm{CdS} \cdot\left(\mathrm{CdCO}_{3} \cdot \mathrm{Se}\right)$. The samples were heat-treated at 400,500 , 600 or $700^{\circ} \mathrm{C}$ for an hour, 5 hours or 25 hours. On the other hand, the other samples, with addition of $1 \mathrm{wt} \%$ sulfur powder, were heat-treated to study the effect of the atmospheric gas on sulfur addition.

Heat-treated samples were investigated by the measurement of $\mathrm{X}$-ray diffraction, surface area, electron microscopy, spectral reflectance curve, and chemical analysis.

The results showed that the values of the content of hexagonal-form, particle size and color took the similar changes on heat treatment and a tendency for saturation after five hours. The effects on heat treatment were reduced by the addition of sulfur to the samples.

$\dagger$ Studies of cadmium series pigments. V.

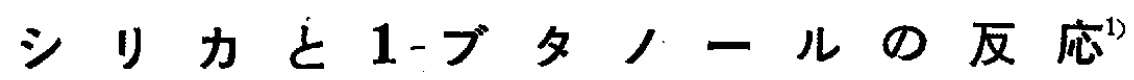

(1972 年 3 月 21 日 受 理)

\section{堤 和 男・高 橋 浩*}

シリカダルをブタノール姏理することによりシリカダル表面を改質し，DTA，赤外吸取，水分吸着能，漫清熱の測 定などを行なった。シリカ表面の水酸基はブタノール処理することによりブトキシ基に变わることが, 一 OH の伸縮 振野強度の減少と一CH の伸樎振動の発現から示された。また改質シリカの水への親和性は低下する。すなわち, 水 分吸着能はるとのシリカにくらへていちじるしく减少する。水への漫渍熱はブタノール処理することによりるとのッ リカの 50〜70\% K低下する。生成したブトキシ基は $400^{\circ} \mathrm{C}$ に排気してるわずかに分解するた゚けである。

\section{1 粕言}

シリカ、アルミナ，チタニアなとの表面は通常䒾面水酸基で特 おわれており親水性を示す。加熱すると水酸基は縮合脱水して表 面には酸妻ブリッジが生じ眯水性になることが多い。これらの表 面官能基は種々の化学反応性を示すことが知られている。たとえ ば固体酸触媒として知られるシリカ・アルミナでは表面水酸基の プロトンが酸点として働くことが塩基の吸着などによりかかって いる2)。

シリカ表面の水酸基（シラノール）の反応性についてはいくつ

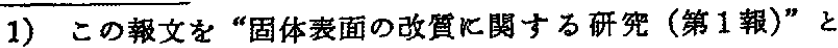
する.

* 東京大学生産技衔研究所，東京都港区六本木
かの報告がある。その研究は特るとシラノールの同定を対象とし

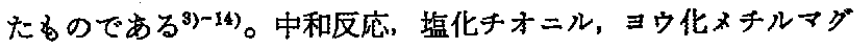
ネシウム, メチルリチウム, ジボラン, 水素化アルミニウムリチ ウム, 三塩化ホウ素, 塩化アルミニウム, 塩化チタン(N), ショ ン誘導体なととの反応である。これらはすべてシラノールの水素

2) W. H. Tamele, Discuss. Faraday Soc., 8, 270(1950); T. H. Milliken, G. A. Mills, A. G. Oblad, ibid., 8, 280 (1950).

3) H. P. Boehm, Angew. Chem., 78, 617(1966).

4) H. P. Boehm, Advan. Catal., 16, 179(1966).

5) D. J. C. Yates, G. W. Dembinski, W. R. Kroll, J. J. Elliott, J. Phys. Chem., 73, 911(1969).

6) C. G. Armisted, J. A. Hockey, Trans. Faraday Soc., 63, 2549(1967). 